\title{
Millennial Lecturer in Higher Education: The Effect of Knowledge Clusters, Performance and Learning Satisfaction on Learning Outcomes
}

\author{
Vini Mariani ${ }^{1}{ }^{\dagger} \ddagger$, Agus Putranto ${ }^{2 \ddagger}$, Ilona Gutanjala ${ }^{3 \ddagger}$, and Teguh Prasandy ${ }^{2, *}$ \\ 1 Bina Nusantara University; vmariani@binus.edu \\ 2 Bina Nusantara University; aputra@binus.edu \\ 3 Bina Nusantara University; ilonagutanjala@binus.ac.id \\ $4 \quad$ Bina Nusantara University; teguh.prasandy@binus.edu \\ * Correspondence: teguh.prasandy@binus.edu; Tel.: +62 85641841858 (INA) \\ $\dagger \quad$ Current address: Jl. KH Syahdan No. 9 Kemanggisan, West Jakarta, Jakarta Indonesia
}

\begin{abstract}
Generation $\mathrm{Y}$ is known as job jumpers because of the desire to earn a higher salary, career opportunities and opportunities to develop themselves. One type of work is a teacher because by becoming a teacher they get a better life, one of which is by getting extra income from the government for those who already have teacher certification, this is what encourages Generation $Y$ to choose this profession. this study uses crosstabs for the data analysis process because the data comes from the LMS database owned by XYZ Campus. Millennial educators who have the highest performance value of PJJ Information Systems for Information System Engineering Cluster with a value of 5.19. The impact of transactions on millennial lecturers on students is able to fulfill any given workload. Appreciate millennial lecturers in tangible and intangible forms.
\end{abstract}

Keywords: Millennial Lecturer, Knowledge Clusters, Performance, Learning Satisfaction, Learning Outcomes

\section{Introduction}

Generation $\mathrm{Y}$ is known as job jumpers because of the desire to earn a higher salary, career opportunities and opportunities to develop themselves. Some of the things according to statement [1] so that Generation $Y$ loves their work and is very loyal is to make the work fun for them. One type of work is a teacher because by becoming a teacher they get a better life, one of which is by getting extra income from the government for those who already have teacher certification, this is what encourages Generation $Y$ to choose this profession. In addition, Generation $Y$ feels by becoming a teacher that they can actualize and develop themselves. Both are forms of higher education dharma. Self-actualization is reflected in the form of teaching, which will be seen in the dedication of students' achievements and learning outcomes, while self-development is reflected in the participation of teachers in events such as workshops or training courses conducted by internal and external campus.

For the other two dharmas of higher education in the form of research and community service. The form of research is publication in the form of scientific articles that are published in journals and seminar reports. While for Community Service in the form of providing training in providing the knowledge that a teacher has to the community. Of all the dharma activities listed above as a commitment performed every semester, it becomes a teacher's performance load activity report to be eligible to obtain teacher certification grants each semester.

The aim of this research was conducted at Campus XYZ as one of the educational institutions offering distance learning where teachers can teach through the Learning Management System (LMS) and do not require data on campus so that many applicants, especially from generation $Y$, on this campus, because apart from working as professionals, they can still work as a teacher. After they 
pass the long test, the teacher will be placed according to their scientific linearity. Some of them are in the distance learning information system and management distance learning study program.

The current situation is due to the Covid19 pandemic, in which the government set aside learning at home so that many campuses put Education and Learning Activities (KBM) online. As a result, the number of new students (intake) of the PJJ Information System and PJJ Management program is increasing strongly, as a result of which the transaction of teaching and learning activities has also increased and the need for teachers (lecturer) has increased.

Campus $\mathrm{XYZ}$ as one of the educational institutions has an independent assessment that conducts lecturer performance assessments in the form of a teacher academic performance index whose value is accumulated in the annual performance of the teachers that can be seen through the LMS. The performance value is included as a consideration in the assignment of lecturer in the following year. With this assessment, Gen Y lecturer can find out their achievements and dedication in teaching and impact the achievement and fulfillment of students' learning outcomes.

According to [2], a statistical data fusion model that allows statistical association tests using multiple imputations presented an overview of this approach with an application comparing the crosstab results of combined data with those obtained from complete data. Meanwhile [3] Crosstab is running in a column database management system. The column database management system determines the value of the crosstab operation for each result row and determines the value for the result column of the row combination as an aggregated value based on the intersection set record. From these two publications, this study uses crosstabs for the data analysis process because the data comes from the LMS database owned by XYZ Campus.

From the description above, this research is titled Millennial Lecturers in Higher Education: The Effect of Knowledge Clusters, Performance, and Learning Satisfaction on Learning Outcomes.

\section{Formulation}

In the current study, we question:

1. The problem in this study is how to analyze the relationship between millennium lecturers and knowledge, performance and learning satisfaction on learning outcomes?

\section{Scope of study}

The scope of our study are:

1. Use of education and learning transaction data in the PJJ SI and PJJ Management XYZ courses.

2. Use student learning outcomes to see the impact of teaching and learning activities on student performance.

3. Using data for the $2017 / 2018,2018 / 2019,2019 / 2020$ academic year.

4. The Information Systems PJJ study program is limited to Information Systems Engineering clusters, a Management Study Program knowledge cluster for a specialization in Global Business Management.

5. Use of the Microsoft Excel application in data processing.

\section{Research Objective}

The research objective this paper are:

1. Analysis of the impact of knowledge clusters on millennial lecturer.

2. Analysis of the impact of lecturer on transactions of teaching and learning activities.

3. Treatment Suggest solutions to millennial lecturer.

\section{Literature}

The millennial generation is the millennial generation or what is also called the $\mathrm{Y}$ generation, born around 1980 to 2000 . Thus, it can be said that the millennial generation is the young generation of today who is currently about 15-34 years old. The age range is in line with the average age of students currently studying at tertiary institutions, ie between 19 and 34 years [4]. 
$\mathrm{XYZ}$ conducts college activities online and face-to-face through a website-based platform as a learning medium for students. This is so that learning can be done flexibly, students can learn anywhere, anytime. This is very supportive for students who are busy as employees, entrepreneurs. And now online learning is also starting to become interesting for SMA / SMK graduates. As for the learning platform with Learning Management Systems [5]. the challenge of creating, modifying, and analyzing data generated from simulations in online classes, it is important that we know more about how students use simulations and model the data they generate in online learning environments [6].

Cross tabulations of dosage clusters and Stage of Change response categories with themes from the open-ended survey items provided a finer-grained look into the question of what factors were associated with the highest levels of PBEE teacher practice change [7]. Crosstab analysis is a descriptive analysis used to determine the relationship between two variables. Crosstab analysis allows users to cross data from one variable to another. Crosstab analysis can be performed on ordinal or nominal variables [8].

\section{Materials and Methods}

The research method used is cross tables in the table:

1. The learning outcomes of each subject in the Information System Engineering Cluster, majoring in Information Systems

2. The learning outcomes of each subject in the Global Business Management Cluster, majoring in business management

3. Continuity of the educational information system PJJ teachers for the Information Systems Engineering cluster, so that the most consistent teacher in Information System Engineering Classroom Learning

4. Continuity of Teaching PJJ Management Teachers for Global Business Management Cluster, so that the most consistent teacher in teaching PJJ Management for Global Business Management Science Cluster is obtained.

5. Teacher Birthday and Teacher Performance Value PJJ Information Systems for Information System Engineering Cluster.

6. Lecturer Date of Birth and Performance Value of PJJ Management for Global Business Management Cluster.

After the data is tabulated, it is compared to the results of teacher performance in business-managed information systems so that Millennial teachers have the best KPIs between the two courses.

\section{Results}

The PJJ Information System and PJJ Management course was established in 2015. From the outset, this training was quite attractive to the public, according to new students for the PJJ Information System and PJJ Management Training, which has increased every year.

Table 1. Data for New Admission to PJJ Information Systems and PJJ Management

\begin{tabular}{|l|c|c|c|}
\hline \multirow{2}{*}{\multicolumn{1}{|c|}{ Study Program }} & \multicolumn{3}{c|}{ Academic Year } \\
\cline { 2 - 4 } & $\mathbf{2 0 1 7 / 2 0 1 8}$ & $\mathbf{2 0 1 8 / 2 0 1 9}$ & $\mathbf{2 0 1 9 / 2 0 2 0}$ \\
\hline Business Management & 762 & 811 & 827 \\
\hline Information Systems & 477 & 425 & 567 \\
\hline
\end{tabular}




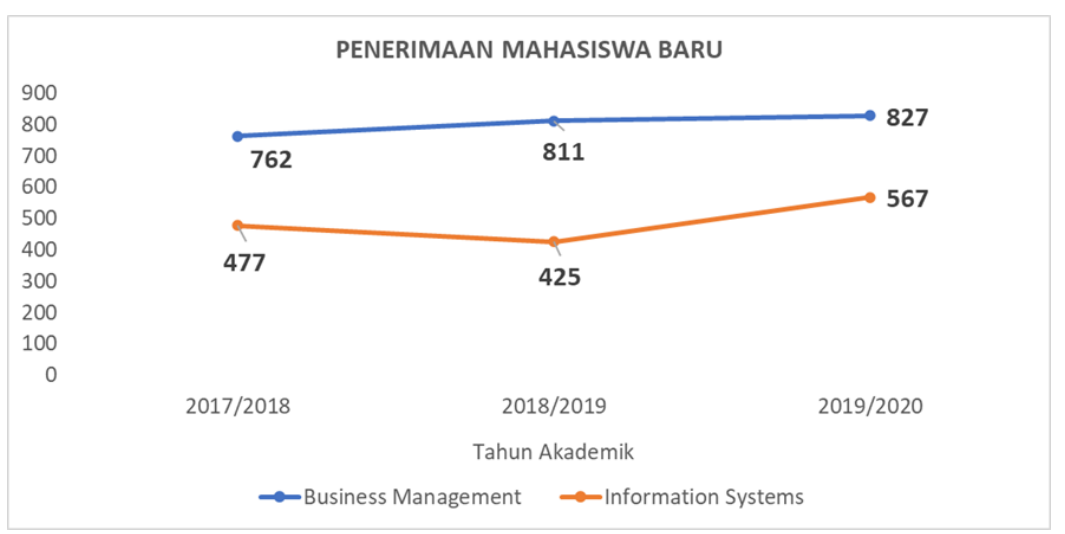

Figure 1. Fig. 1. Data for New Admission to PJJ Information Systems and PJJ Management By looking at the above chart, PJJ Business Management is in the range of 800 and PJJ for information systems is in the range of 450 . With this estimate there will be a higher increase next year given the existence of government policies applying online colleges to all levels of education. The method used in the learning process is done online and in person through video conferencing. The online method is asyn-chronous through the Learning Management System, which requires more independ-ent learning from students.

The activities that students must perform to measure student performance in-clude:

1. Student activity in posting discussion forums, conducted weekly according to the topic

2. The presence of face-to-face (video conference) students, there were 6 video conference activities

3. Quizzes twice

4. Personal Assignment twice

5. Group assignments 4 times

6. Final Test once

For the activity of students posting discussion forums, the presence of face-to-face students, quiz assessments are conducted through the system. In the case of personal assignment assessments, group assignments and exams are carried out by the lecturer. Each topic, each student topic, has provided the main material and sup-port material to be studied. Quiz questions, personal assignment questions and group assignment questions were also asked from the start of the meeting.

Following are the learning outcomes students achieved for the 2017/2018, 2018/2019 and 2019/2020 academic years. PJJ Information Systems for Information System Engineering Clusters of courses and learning outcomes are shown in Table 2 and Figure 2.

Table 2. Information System PJJ Learning Outcomes Data for Information System Engineering Cluster

\begin{tabular}{|c|c|c|c|c|c|c|c|c|c|c|c|c|c|}
\hline $\begin{array}{c}\text { Academic } \\
\text { Year }\end{array}$ & $\begin{array}{l}\text { Course } \\
\text { Code }\end{array}$ & Course Description & $\begin{array}{l}\text { Total } \\
\text { Unit }\end{array}$ & $\begin{array}{l}\text { Total } \\
\text { student }\end{array}$ & Average & A & A- & B+ & B & B- & $\mathrm{C}$ & $\mathbf{D}$ & $\mathbf{E}$ \\
\hline $2017 / 2018$ & ISYS6300 & Business Process Fundamental & 4 & 1004 & 75.33 & 160 & 240 & 196 & 144 & 76 & 32 & 46 & 110 \\
\hline $2017 / 2018$ & ISYS6308 & User Experience & 4 & 594 & 82.49 & 222 & 114 & 108 & 62 & 36 & 8 & 12 & 32 \\
\hline $2017 / 2018$ & ISYS6311 & Advanced Information Systems Analysis and Design & 6 & 204 & 76.07 & 46 & 76 & 28 & 12 & 6 & 8 & 4 & 24 \\
\hline
\end{tabular}




\begin{tabular}{llllllllllllll}
\hline $2018 / 2019$ & ISYS6300 & Business Process Fundamental & 4 & 947 & 75.89 & 224 & 157 & 119 & 129 & 100 & 74 & 48 & 96 \\
\hline $2018 / 2019$ & ISYS6308 & User Experience & 4 & 867 & 83.35 & 300 & 198 & 140 & 120 & 46 & 14 & 31 & 18 \\
\hline $2018 / 2019$ & ISYS6311 & Advanced Information Systems Analysis and Design & 6 & 236 & 77.62 & 44 & 54 & 40 & 32 & 24 & 14 & 12 & 16 \\
\hline $2019 / 2020$ & ISYS6300 & Business Process Fundamental & 4 & 1152 & 80.48 & 402 & 250 & 144 & 116 & 76 & 54 & 38 & 72 \\
\hline $2019 / 2020$ & ISYS6308 & User Experience & 4 & 300 & 83.31 & 68 & 94 & 66 & 24 & 18 & 8 & 18 & 4 \\
\hline $2019 / 2020$ & ISYS6311 & Advanced Information Systems Analysis and Design & 6 & 190 & 82.57 & 90 & 32 & 18 & 20 & 10 & 4 & 4 & 12 \\
\hline
\end{tabular}

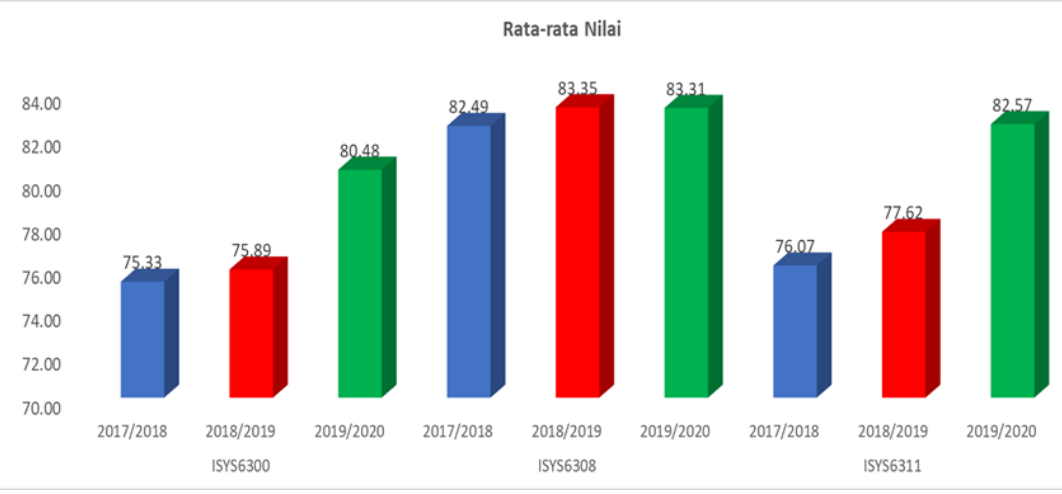

Figure 2. Information System PJJ Learning Outcomes Data for Information System Engineer-ing Cluster

The Information Systems PJJ curriculum for the Information Systems Engineer-ing Cluster consists of ISYS6300 - Business Process Fundamental, ISYS6308 - User Experience, and ISYS6311 Advanced Information Systems Analysis and Design topics. The Information System Engineering PJJ course scores an average of 79.68 .

Each course shows an increase in value every academic year. PJJ Management for Global Business Management Cluster with courses is shown in Table 3 and Figure 3.

Table 3. Data on learning outcomes from PJJ Management for Global Business Management Cluster

\begin{tabular}{ccccccccccccccc}
\hline $\begin{array}{c}\text { Tahun } \\
\text { Ajaran }\end{array}$ & $\begin{array}{c}\text { Course } \\
\text { Code }\end{array}$ & Course Description & $\begin{array}{c}\text { Total } \\
\text { Unit }\end{array}$ & $\begin{array}{c}\text { Jlh } \\
\text { Mhs }\end{array}$ & $\begin{array}{c}\text { Rata-rata } \\
\text { Nilai }\end{array}$ & A & A- & B+ & B & B- & C & D & E \\
\hline $2017 / 2018$ & BUSS6048 & International Business & 4 & 506 & 72.58 & 48 & 82 & 100 & 72 & 52 & 34 & 62 & 56 \\
\hline $2017 / 2018$ & MGMT6160 & Global Supply Chain Management & 4 & 322 & 71.27 & 22 & 52 & 62 & 64 & 30 & 24 & 20 & 48 \\
\hline $2018 / 2019$ & BUSS6048 & International Business & 4 & 654 & 74.87 & 86 & 118 & 158 & 92 & 56 & 34 & 60 & 50 \\
\hline $2018 / 2019$ & MGMT6160 & Global Supply Chain Management & 4 & 582 & 78.95 & 90 & 152 & 110 & 92 & 58 & 28 & 22 & 30 \\
\hline $2019 / 2020$ & BUSS6048 & International Business & 4 & 370 & 77.14 & 38 & 108 & 82 & 44 & 42 & 20 & 16 & 20 \\
\hline $2019 / 2020$ & MGMT6160 & Global Supply Chain Management & 4 & 744 & 80.78 & 192 & 206 & 134 & 78 & 44 & 36 & 24 & 30 \\
\hline
\end{tabular}

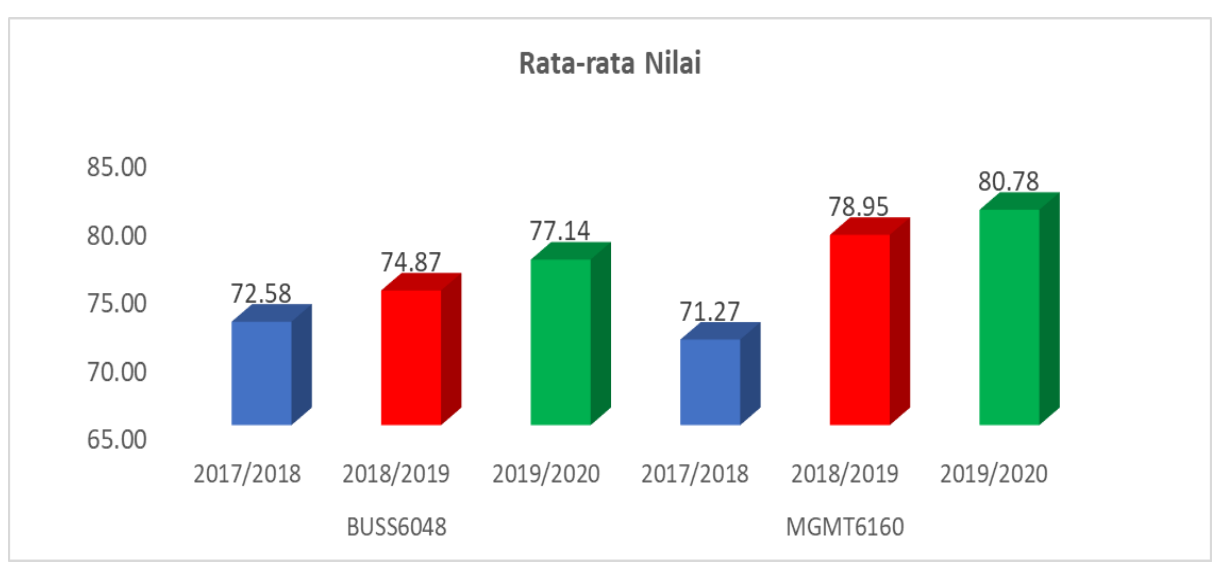

Figure. 3. PJJ Management Learning Outcomes for Global Business Management Cluster 
The PJJ Management Study Program for Global Business Management Cluster consists of the courses BUSS6048 - International Business and MGMT6160 - Global Supply Chain Management. The Global Business Management PJJ study program has an average score of 77.84. Each course shows an increase in value every academic year.

Lecturers teaching in Information Systems Engineering PJJ study program for In-formation Systems Engineering cluster consist of ISYS6300 - Business Process Fun-damental, ISYS6308 - User Experience and ISYS6311 - Advanced Information Sys-tems Analysis and Design, there are 30 lecturers with lesson details in table 4 \& 5 .

Table 4. Continuity of Education Data for Information System Engineering Lecturers from PJJ for Information System Engineering Cluster

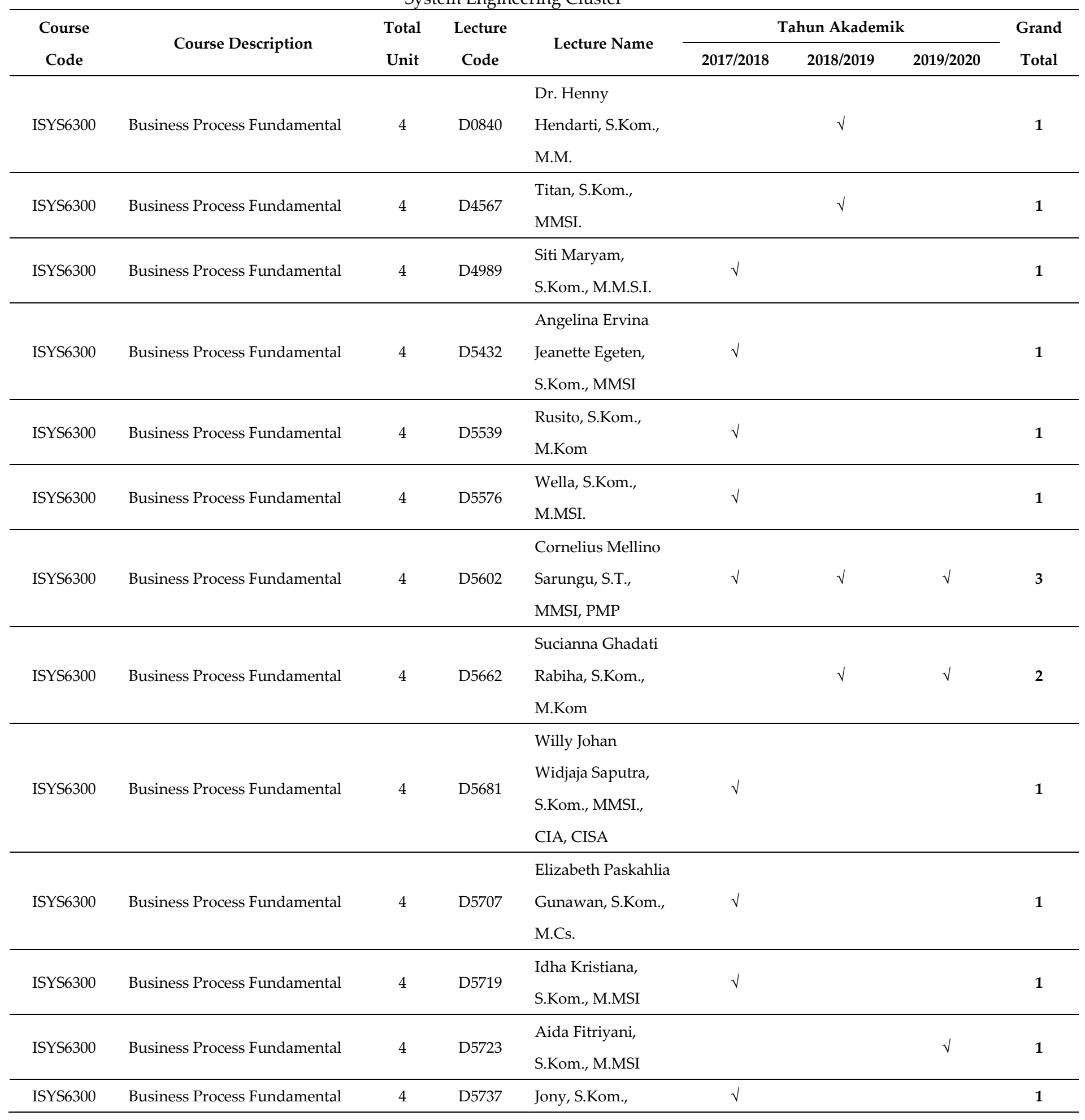


M.Kom.

\begin{tabular}{|c|c|c|c|c|c|c|c|c|}
\hline ISYS6300 & Business Process Fundamental & 4 & D5786 & $\begin{array}{l}\text { Dina Fitria Murad, } \\
\text { S.Kom., M.Kom. }\end{array}$ & $\sqrt{ }$ & $\sqrt{ }$ & & 2 \\
\hline ISYS6300 & Business Process Fundamental & 4 & D6087 & $\begin{array}{l}\text { Atikah, S.Kom., } \\
\text { M.MSI }\end{array}$ & & $\sqrt{ }$ & & 1 \\
\hline ISYS6300 & Business Process Fundamental & 4 & D6091 & $\begin{array}{l}\text { Laser Narindro, } \\
\text { ST., M.MSI }\end{array}$ & & $\sqrt{ }$ & & 1 \\
\hline ISYS6300 & Business Process Fundamental & 4 & D6147 & $\begin{array}{l}\text { Meta Amalya } \\
\text { Dewi, S.Kom,. } \\
\text { M.Kom }\end{array}$ & & $\sqrt{ }$ & $\sqrt{ }$ & 2 \\
\hline ISYS6308 & User Experience & 4 & D4630 & $\begin{array}{l}\text { Lius Steven } \\
\text { Sanjaya, S.Kom., } \\
\text { MMSI. }\end{array}$ & $\sqrt{ }$ & & & 1 \\
\hline ISYS6308 & User Experience & 4 & D5471 & Lena S.Kom., M.M & $\sqrt{ }$ & $\sqrt{ }$ & $\sqrt{ }$ & 3 \\
\hline ISYS6308 & User Experience & 4 & D5539 & $\begin{array}{l}\text { Rusito, S.Kom., } \\
\text { M.Kom }\end{array}$ & $\sqrt{ }$ & $\sqrt{ }$ & $\sqrt{ }$ & 3 \\
\hline ISYS6308 & User Experience & 4 & D5786 & $\begin{array}{l}\text { Dina Fitria Murad, } \\
\text { S.Kom., M.Kom. }\end{array}$ & & $\sqrt{ }$ & & 1 \\
\hline ISYS6308 & User Experience & 4 & D6090 & $\begin{array}{l}\text { Hermawan } \\
\text { Honggo Widagdo, } \\
\text { S.Kom., M.M. }\end{array}$ & & $\sqrt{ }$ & & 1 \\
\hline ISYS6308 & User Experience & 4 & D6149 & $\begin{array}{l}\text { Fauzan } \\
\text { Fahruzzaman, } \\
\text { S.Kom., M.Kom. }\end{array}$ & & $\sqrt{ }$ & & 1 \\
\hline ISYS6311 & $\begin{array}{l}\text { Advanced Information Systems } \\
\text { Analysis and Design }\end{array}$ & 6 & D0840 & $\begin{array}{l}\text { Dr. Henny } \\
\text { Hendarti, S.Kom., } \\
\text { M.M. }\end{array}$ & & & $\sqrt{ }$ & 1 \\
\hline ISYS6311 & $\begin{array}{l}\text { Advanced Information Systems } \\
\text { Analysis and Design }\end{array}$ & 6 & D3582 & $\begin{array}{l}\text { Maria Gabby, } \\
\text { S.Kom., MMSI. }\end{array}$ & & $\sqrt{ }$ & & 1 \\
\hline ISYS6311 & $\begin{array}{l}\text { Advanced Information Systems } \\
\text { Analysis and Design }\end{array}$ & 6 & D4667 & $\begin{array}{l}\text { Natalia Limantara, } \\
\text { S.Kom., MMSI. }\end{array}$ & & & $\sqrt{ }$ & 1 \\
\hline ISYS6311 & $\begin{array}{l}\text { Advanced Information Systems } \\
\text { Analysis and Design }\end{array}$ & 6 & D4716 & $\begin{array}{l}\text { Stephanie Surja, } \\
\text { S.Kom, MMSI. }\end{array}$ & & & $\sqrt{ }$ & 1 \\
\hline ISYS6311 & $\begin{array}{l}\text { Advanced Information Systems } \\
\text { Analysis and Design }\end{array}$ & 6 & D4900 & $\begin{array}{l}\text { Veronica, S.Kom., } \\
\text { M.M.S.I. }\end{array}$ & & $\sqrt{ }$ & & 1 \\
\hline ISYS6311 & $\begin{array}{l}\text { Advanced Information Systems } \\
\text { Analysis and Design }\end{array}$ & 6 & D5786 & $\begin{array}{l}\text { Dina Fitria Murad, } \\
\text { S.Kom., M.Kom. }\end{array}$ & $\sqrt{ }$ & $\sqrt{ }$ & & 2 \\
\hline ISYS6311 & $\begin{array}{l}\text { Advanced Information Systems } \\
\text { Analysis and Design }\end{array}$ & 6 & D6090 & $\begin{array}{l}\text { Hermawan } \\
\text { Honggo Widagdo, } \\
\text { S.Kom., M.M. }\end{array}$ & & $\sqrt{ }$ & & 1 \\
\hline Grand Total & & & & & 14 & 17 & 9 & 40 \\
\hline
\end{tabular}


Of the 30 lecturers who teach in the Information Systems Engineering PJJ course of the Information Systems Engineering Cluster, only 3 lecturers teach the same subject every year, table 5 shows.

Table 5. Most consistent lecturer data when teaching PJJ Information Systems for the information systems cluster

\begin{tabular}{|c|c|c|c|c|c|c|c|c|}
\hline \multirow{2}{*}{$\begin{array}{l}\text { Course } \\
\text { Code }\end{array}$} & \multirow{2}{*}{ Course Description } & \multirow{2}{*}{$\begin{array}{l}\text { Total } \\
\text { Unit }\end{array}$} & \multirow{2}{*}{$\begin{array}{c}\text { Lecture } \\
\text { Code }\end{array}$} & \multirow{2}{*}{ Lecture Name } & \multicolumn{3}{|c|}{ Tahun Akademik } & \multirow{2}{*}{$\begin{array}{l}\text { Grand } \\
\text { Total }\end{array}$} \\
\hline & & & & & $2017 / 2018$ & $2018 / 2019$ & $2019 / 2020$ & \\
\hline ISYS6300 & Business Process Fundamental & 4 & D5602 & $\begin{array}{l}\text { Cornelius Mellino } \\
\text { Sarungu, S.T., } \\
\text { MMSI, PMP }\end{array}$ & $\sqrt{ }$ & $\sqrt{ }$ & $\sqrt{ }$ & 3 \\
\hline ISYS6308 & User Experience & 4 & D5471 & $\begin{array}{l}\text { Lena S.Kom., } \\
\text { M.M }\end{array}$ & $\sqrt{ }$ & $\sqrt{ }$ & $\sqrt{ }$ & 3 \\
\hline ISYS6308 & User Experience & 4 & D5539 & $\begin{array}{l}\text { Rusito, S.Kom., } \\
\text { M.Kom }\end{array}$ & $\sqrt{ }$ & $\sqrt{ }$ & $\sqrt{ }$ & 3 \\
\hline
\end{tabular}

There are 11 lecturers teaching in the PJJ Management Study Program for the Global Business Management Science Cluster, consisting of BUSS6048 - Interna-tional Business and MGMT6160 Global Supply Chain Management courses, with 11 lecturers with lesson details in Table 6.

Table 6. Continuity of education data for PJJ Management lecturers for Global Business Management Cluster

\begin{tabular}{|c|c|c|c|c|c|c|c|c|}
\hline \multirow{2}{*}{$\begin{array}{l}\text { Course } \\
\text { Code }\end{array}$} & \multirow{2}{*}{ Course Description } & \multirow{2}{*}{$\begin{array}{l}\text { Total } \\
\text { Unit }\end{array}$} & \multirow{2}{*}{$\begin{array}{l}\text { Lecture } \\
\text { Code }\end{array}$} & \multirow{2}{*}{ Lecture Name } & \multicolumn{3}{|c|}{ Tahun Akademik } & \multirow{2}{*}{$\begin{array}{l}\text { Grand } \\
\text { Total }\end{array}$} \\
\hline & & & & & $2017 / 2018$ & $2018 / 2019$ & $2019 / 2020$ & \\
\hline BUSS6048 & International Business & 4 & D5154 & $\begin{array}{l}\text { Shelvy Kurniawan, } \\
\text { S.E., M.M. }\end{array}$ & $\sqrt{ }$ & $\sqrt{ }$ & $\sqrt{ }$ & 3 \\
\hline BUSS6048 & International Business & 4 & D5440 & Novita, S.Kom., MBA & $\sqrt{ }$ & $\sqrt{ }$ & & 2 \\
\hline BUSS6048 & International Business & 4 & D5451 & $\begin{array}{l}\text { Dr. Ridho Bramulya } \\
\text { Ikhsan, S.E., MM }\end{array}$ & $\sqrt{ }$ & & $\sqrt{ }$ & 2 \\
\hline BUSS6048 & International Business & 4 & D5564 & $\begin{array}{l}\text { Dr. dr. Ferdi Antonio, } \\
\text { M.M }\end{array}$ & $\sqrt{ }$ & $\sqrt{ }$ & $\sqrt{ }$ & 3 \\
\hline BUSS6048 & International Business & 4 & D5630 & $\begin{array}{l}\text { Rudy Kodirun, S.E., } \\
\text { M.M }\end{array}$ & $\sqrt{ }$ & $\sqrt{ }$ & & 2 \\
\hline & & & & $\begin{array}{l}\text { Mochammad Fahlevi, } \\
\text { S.Pd.I., M.M., M.A., }\end{array}$ & & & $\sqrt{ }$ & \\
\hline BUSS6048 & International Business & 4 & D6255 & M.Ud., AWP & & & & 1 \\
\hline MGMT6160 & Global Supply Chain Management & 4 & D5289 & $\begin{array}{l}\text { Yudi Fernando, S.E., } \\
\text { M.B.A., Ph.D., MLogM }\end{array}$ & & $\sqrt{ }$ & $\sqrt{ }$ & 2 \\
\hline MGMT6160 & Global Supply Chain Management & 4 & D5389 & $\begin{array}{l}\text { Dony Saputra, S.Kom, } \\
\text { M.M., M.Kom }\end{array}$ & $\sqrt{ }$ & & & 1 \\
\hline MGMT6160 & Global Supply Chain Management & 4 & D5451 & $\begin{array}{l}\text { Dr. Ridho Bramulya } \\
\text { Ikhsan, S.E., MM }\end{array}$ & $\sqrt{ }$ & $\sqrt{ }$ & $\sqrt{ }$ & 3 \\
\hline MGMT6160 & Global Supply Chain Management & 4 & D5630 & $\begin{array}{l}\text { Rudy Kodirun, S.E., } \\
\text { M.M }\end{array}$ & & & $\sqrt{ }$ & 1 \\
\hline MGMT6160 & Global Supply Chain Management & 4 & D5728 & $\begin{array}{l}\text { Yudhita Valen } \\
\text { Prasarry, S.AB., M.AB. }\end{array}$ & $\sqrt{ }$ & $\sqrt{ }$ & $\sqrt{ }$ & 3 \\
\hline
\end{tabular}


Of the 11 lecturers who teach in the PJJ Management program in the Global Business Management Cluster, only 4 lecturers teach the same subject every year, as shown in table 7 .

Table 7. Most Consistent Lecturer Data in Teaching PJJ Management for Global Business Management Cluster

\begin{tabular}{|c|c|c|c|c|c|c|c|c|}
\hline \multirow{2}{*}{ Course Code } & \multirow{2}{*}{ Course Description } & \multirow{2}{*}{$\begin{array}{l}\text { Total } \\
\text { Unit }\end{array}$} & \multirow{2}{*}{$\begin{array}{l}\text { Lecture } \\
\text { Code }\end{array}$} & \multirow{2}{*}{ Lecture Name } & \multicolumn{3}{|c|}{ Tahun Akademik } & \multirow{2}{*}{$\begin{array}{l}\text { Grand } \\
\text { Total }\end{array}$} \\
\hline & & & & & $2017 / 2018$ & 2018/2019 & $2019 / 2020$ & \\
\hline BUSS6048 & International Business & 4 & D5154 & Shelvy Kurniawan, S.E., M.M. & $\sqrt{ }$ & $\sqrt{ }$ & $\sqrt{ }$ & 3 \\
\hline BUSS6048 & International Business & 4 & D5564 & Dr. dr. Ferdi Antonio, M.M & $\sqrt{ }$ & $\sqrt{ }$ & $\sqrt{ }$ & 3 \\
\hline MGMT6160 & Global Supply Chain Management & 4 & D5451 & Dr. Ridho Bramulya Ikhsan, S.E., MM & $\sqrt{ }$ & $\sqrt{ }$ & $\sqrt{ }$ & 3 \\
\hline MGMT6160 & Global Supply Chain Management & 4 & D5728 & Yudhita Valen Prasarry, S.AB., M.AB. & $\sqrt{ }$ & $\sqrt{ }$ & $\sqrt{ }$ & 3 \\
\hline
\end{tabular}

From here it can be seen that in the PJJ Information System course and the PJJ Management Course, there are changes per subject in the lecturers who teach per academic year. Changes in lecturers per study period are due to the busyness of the lecturers. Each academic year, the lecturer receives a willingness to teach form from the Operations section to fill in the lecturer's willingness to teach, in order to predict the number of subject transactions with the availability of lecturers. If the number of transactions is large and the willingness of lecturers is small, the Operations section will inform the study program in order to be able to inform the lecturer who is scheduled for the course. And if there is no willingness to be scheduled for the course, the program will admit new lecturers.

Table 8. Data of the date of birth of lecturers and the performance values of Lecturers of PJJ Information Systems for the cluster for information systems engineering

\begin{tabular}{|c|c|c|c|c|c|}
\hline \multirow{2}{*}{$\begin{array}{c}\text { Lecturer } \\
\text { Code }\end{array}$} & \multirow{2}{*}{ Lecturer Name } & \multirow{2}{*}{ Tanggal Lahir } & \multicolumn{3}{|c|}{ Tahun Akademik } \\
\hline & & & 2017 & 2018 & 2019 \\
\hline D4567 & Titan, S.Kom., MMSI. & 22-Jan-85 & & 4,95 & \\
\hline D4630 & Lius Steven Sanjaya, S.Kom., MMSI. & 24-Apr-89 & 4,89 & & \\
\hline D4667 & Natalia Limantara, S.Kom., MMSI. & 21-Dec-88 & & & 5,14 \\
\hline D4716 & Stephanie Surja, S.Kom, MMSI. & 7-Feb-87 & & & 5,19 \\
\hline D4900 & Veronica, S.Kom., M.M.S.I. & 10-Aug-87 & & 4,64 & \\
\hline D5432 & Angelina Ervina Jeanette Egeten, S.Kom., MMSI & 19-Dec-90 & 4,69 & & \\
\hline D5471 & Lena S.Kom., M.M & 17-Mar-80 & 4,60 & 4,84 & 4,91 \\
\hline D5576 & Wella, S.Kom., M.MSI. & 5-Nov-91 & 4,96 & & \\
\hline D5662 & Sucianna Ghadati Rabiha, S.Kom., M.Kom & 15-Apr-89 & & 4,66 & 4,96 \\
\hline
\end{tabular}




\begin{tabular}{|c|c|c|c|c|c|}
\hline D5707 & Elizabeth Paskahlia Gunawan, S.Kom., M.Cs. & 15-Apr-90 & 4,77 & & \\
\hline D5719 & Idha Kristiana, S.Kom., M.MSI & $10-F e b-88$ & 4,74 & & \\
\hline D5723 & Aida Fitriyani, S.Kom., M.MSI & 2-Jul-85 & & & 4,70 \\
\hline D6090 & Hermawan Honggo Widagdo, S.Kom., M.M. & 2-Mar-83 & & 4,78 & \\
\hline D6091 & Laser Narindro, ST., M.MSI & 31-Aug-87 & & 4,87 & \\
\hline D6147 & Meta Amalya Dewi, S.Kom,. M.Kom & 12-May-80 & & 4,94 & 4,86 \\
\hline D6149 & Fauzan Fahruzzaman, S.Kom., M.Kom. & 20-Feb-91 & & 4,70 & \\
\hline Rata-rata & & & 4,67 & 4,80 & 4,93 \\
\hline
\end{tabular}

Table 8. It can be seen that millennial lecturers achieved an average score of 4.67 in 2017, 4.80 in 2018 and 4.93 in 2019. So it can be seen that the performance value of lecturers is increasing every year. If you look at the lecturers, you can see that the highest was achieved in 2018 by lecturers born in 1985, while in 2019 the highest was achieved by lecturers born in 1987.

Table 9. Data Lecturer Date of Birth and Performance Value of PJJ Management for Global Business Management Cluster

\begin{tabular}{|c|c|c|c|c|c|}
\hline \multirow{2}{*}{$\begin{array}{l}\text { Lecturer } \\
\text { Code }\end{array}$} & \multirow{2}{*}{ Lecturer Name } & \multirow{2}{*}{$\begin{array}{l}\text { Date of } \\
\text { Birth }\end{array}$} & \multicolumn{3}{|c|}{ Academic Year } \\
\hline & & & 2017 & 2018 & 2019 \\
\hline D3582 & Maria Gabby, S.Kom., MMSI. & 6-Jan-87 & & 4,77 & \\
\hline D5154 & Shelvy Kurniawan, S.E., M.M. & 24-Feb-89 & 4,45 & 4,94 & 4,94 \\
\hline D5289 & Yudi Fernando, S.E., M.B.A., Ph.D., MLogM & 5-Jan-80 & & 4,75 & 4,79 \\
\hline D5451 & Dr. Ridho Bramulya Ikhsan, S.E., MM & 25-Sep-80 & 4,91 & 4,98 & 5,14 \\
\hline D5728 & Yudhita Valen Prasarry, S.AB., M.AB. & 31-Jan-90 & 4,41 & 4,88 & 4,93 \\
\hline D6255 & $\begin{array}{l}\text { Mochammad Fahlevi, S.Pd.I., M.M., M.A., M.Ud., } \\
\text { AWP }\end{array}$ & 11-Feb-91 & & 4,87 & \\
\hline Rata-rata & & & 4,63 & 4,80 & 4,93 \\
\hline
\end{tabular}

Table 9 shows that millennial lecturers have an average performance score of 4.63 in 2017, 4.80 in 2018 and 4.93 in 2019. So it can be seen that the performance value of lecturers is increasing every year. If you look at the lecturers, you can see that the highest in 2018 and 2019 was achieved by lecturers born in 1980 or the early millennial generation.

\section{Discussion}


Based on student performance and lecturer changes, it can be seen that lecturer changes have no significant impact on student performance. This can be seen in Figure 2 and Figure 3, that student performance has no significant impact. This is due to the very good control over the material offered in the form of powerpoints, lecturer notes, assignments, quizzes, discussion forums and exam questions, which are largely driven from the PJJ Information Systems department and from Academic Resources XYZ. So that whoever the lecturer is teaching the students has all re-ceived the same material, so that whoever is teaching the lecturer has no impact whatsoever. What has a big influence is the activity of students during the online learning process.

Online learning Student learning performance can be determined, including stu-dent activity on discussion forums, student attendance at personal (video confer-ence) activities, quiz scores, personal assignment scores, group assignment scores, and exam scores. This is evidenced by the active role of students in learning, as the independence of student learning is the key to successful student performance in online learning. Students should be able to organize their own time because the backgrounds of students who have worked is typical of XYZ students.

If the two lumps of science, namely Information System Engineering and Global Business Management, of each academic year are compared, there will be similarity in values, namely in 2017/2018 the highest average of Information System Engineer-ing is 75.33, while in Global Business Management's highest average is 72.58. Meanwhile, the highest number took place in the 2019/2020 academic year, Infor-mation System Engineering, with the highest average at 83.35, while the highest average in Global Business Management was 80.78. The two scores are still in the same range, namely 80-85 in the range of $\mathrm{B}+$ values, so students pass with good grades.

By looking at the good learning results of students, you can see that the lecturers are performing excellently. This is evidenced by various tasks that the lecturer per-forms in each class, such as creating discussion forums, correcting student assign-ments, creating exam questions, and correcting student exams. With so many as-signments, lecturers are still performing well even though they have to fulfill other commitments, especially in the tri dharma of higher education.

This can be seen in the magnitude of the performance value of the lecturer, which continues to increase per academic year, namely 4.80 in 2018 and 4.93 in 2019. If you look at the year of birth of the lecturers of both PJJ Information Systems and PJJ Management, then the highest achieved by lecturers was born in 1987. With this value, the PJJ and PJJ Management Information Systems department gave apprecia-tion in both material and immaterial form to the lecturer with the highest score.

\section{Conclusions}

The conclusions of this paper are:

1. Millennial educators who have the highest performance value of PJJ Infor-mation Systems for Information System Engineering Cluster with a value of 5.19.

2. The impact of transactions on millennial lecturers on students is able to fulfill any given workload.

3. Appreciate millennial lecturers in tangible and intangible forms.

\section{References}

[1] N. Saputra and G. E. Hutajulu, "Engaging the Millennials At Office: Tracking the Antecedents of Holistic Work Engagement," Polish J. Manag. Stud., vol. 21, no. 1, pp. 342-354, 2020, doi: 10.17512/pjms.2020.21.1.25.

[2] W. A. Kamakura and M. Wedel, "Statistical data fusion for cross-tabulation," J. Mark. Res., vol. 34, no. 4, pp. 485-498, 1997, doi: 10.2307/3151966.

[3] I. Graydon, E. Beatty, S. Paul, M. N. Us, and J. A. Hauck, “( 12 ) United States Patent," vol. 1, no. 12, 2006. 
[4] S. Hidayatullah, A. Waris, and R. C. Devianti, "Perilaku Generasi Milenial dalam Menggunakan Aplikasi Go-Food," J. Manaj. Dan Kewirausahaan, vol. 6, no. 2, pp. 240-249, 2018, doi: 10.26905/jmdk.v6i2.2560.

[5] “Kuliah Sambil Kerja, BINUS ONLINE Learning solusinya Informasi program kuliah online berkualitas dengan biaya terjangkau dan jadwal fleksibel." https://onlinelearning.binus.ac.id/ (accessed Sep. 30, 2020).

[6] J. M. Rosenberg and M. A. Lawson, "An investigation of students' use of a computational science simulation in an online high school physics class," Educ. Sci., vol. 9, no. 1, pp. 1-19, 2019, doi: 10.3390/educsci9010049.

[7] M. Duffin and E. E. Perry, "Regional collaboration for sustainability via place-based ecology education: A mixed-methods case study of the upper valley teaching place collaborative," Educ. Sci., vol. 9, no. 1, 2019, doi: 10.3390/educsci9010006.

[8] "//FCS: FUAT CEPAT SELAMAT: ANALISIS CROSS TABULATION (CROSSTAB)." http://fastrans22.blogspot.com/2013/05/analisis-cross-tabulation-crosstab.html (accessed Sep. 27, 2020). 